\section{NECESSIDADE DA UNIDADE DE CRITÉRIO \\ NA SUB-ROGAÇÃO LEGAL, EM FACE DO DIREITO CIVIL E DIREITO COMERCIAL}

\section{Ernesto Martins Vieira}

Professor Catedrático de Direito Comercial da Faculdade de Direito de Goiaz.

Longe de nós a pretensão de dissertar sôbre sub-rogação, perante reunião de tão sábios membros.

Apenas queremos consignar a diversidade de princípios adotados no Direito Civil e no Direito Comercial, dar relêvo à extravagância e afinal propor a unidade de preceitos.

Não é justo que situações semelhantes, situações absolutamente idênticas tenham soluções diferentes, só pelo fato de se tratar de transação puramente civil ou exclusivamente comercial. As obrigações, sejam civis ou comerciais, no que tange à sua anatomia, fisiologia e patologia, pouca diferença apresentam, não sendo, portanto, razoável, que, nos efeitos produzidos por pagamento de terceiro, haja tão radical diversificação de preceitos.

Natural é que se adaptem as leis para uma uniformidade, perfeitamente consentânea com a moral e com os princípios gerais de Direito.

Não iremos historiar a vida do instituto, chamado sub-rogação, através os tempos. Nem apontaremos a deficiência do Direito Romano; nem os delineamentos avançados de Pothier, Dumoulin e Loyseau, fornecendo bases para o Código Napoleônico e da Sardenha; nem criticaremos os Madia, Grappe e Merlin confundindo sub-rogação com cessão ou com novação; também não examinaremos o art. 436 do Código Comercial onde se usa da aberrante expressão "cessionário sub-rogado". Deixaremos de parte a evolução do instituto para focalizá-lo frente aos Códigos modernos e aos ensinamentos dos jurisconsultos que ainda dão lições à atualidade, como Aubry et Rau, Laurent, Baudry Lacantinerie et Barde, Giorgio Giorgi, e, entre os nossos, os dois Carvalho Mendonça, Carvalho dos Santos, Beviláqua, Lacerda de Almeida, etc. etc.

Pelos ensinamentos dos mestres e pelo Código Civil, a sub-rogação pode ser legal ou convencional. Para que se opere a legal, é indispensável que haja um interêsse na pessoa que efetua o pagamento. Sem que êste interêsse interfira, não caberá a sub-rogação legal; então só se poderá falar em sub-rogação convencional, que, como indica a expressão, resultará do assentimento expresso do credor pago, ou do devedor quando êste recebe de terceiro dinheiro para pagar uma dívida com a condição declarada de que o fornecedor do numerário fique sub-rogado na dívida liquidada em face do credor originário.

A sub-rogação legal (êste é o assunto principal dêste trabalho) decorre sòmente de um pagamento por quem tivesse imediato in terêsse em fazê-lo, interêsse ligado à própria dívida. Assim se estabelece em favor do "credor que paga a dívida do devedor comum ao credor, a quem competia o direito de preferência", "do adquirente do imóvel hipotecado, que paga ao credor hipotecário" e finalmente do "terceiro interessado, que paga a dívida pela qual era ou podia ser obrigado, no todo ou em parte" (art. 985 do C. Civil.)

Fora dêstes estritos casos, em lei enumerados, não há como se falar em sub-rogação legal. Um terceiro que, sem qualquer dos interêsses apontados naquele dispositivo legal, viesse a pagar uma dívida alheia, não se investiria em qualquer direito do credor satisfeito. Com base no pagamento sòmente poderá recuperar o dispendido por via da alegação do enriquecimento indébito.

Quem por liberalidade pagou, nenhum direito adquiriu proveniente da pessoa que recebeu. $\mathrm{O}$ direito, de que se reveste contra o devedor beneficiado pelo pagamento, só se estriba na proibição do locupletamento indébito

Este é o princípio do Direito Civil.

Diferente é o Direito Comercial, quando institui as letras de câmbio e as notas promissórias.

A sub-rogação legal, no Direito Civil, só e exclusivamente, se funda no interêsse que teria quem paga, na liquidação da dívida, pouco importando que varios sejam os devedores, pouco importando a natureza do elo obrigacional jungindo todos os co-devedores numa única obrigação.

O Direito Cambiário dispensa a interveniência do interêsse, para que se opere a sub-rogação pleno jure. O simples fato do pagamento, nada mais, cria direitos a favor de quem pagou, sem que a menor sombra de interêsse econômico o levasse àquela liberalidade.

O interveniente, no Dierito Cambiário, é pessoa completamente estranha ao título, que, entretanto, aparece voluntàriamente para pagar (falemos simplesmente da intervenção no pagamento e não no aceite) o valor expresso no título, sem que nenhum interêsse, aparente ou escondido, o levasse à prática do ato. 


$$
-364-
$$

Pelas regras do Direito Civil, o interveniente jamais se sub-rogaria nos direitos expressos pelo título de dívida. Adquiria, quando muito e tão-sòmente, um direito de ressarcimento com base no enriquecimento indébito.

No Direito Cambiário há hipóteses em que o interventor muito legalmente se investe dos direitos consignados na letra de câmbio ou na nota promissória por êle paga.

$\mathrm{O}$ art. 35 da lei 2.044 institui, conforma e dá efeitos ao pagamento por interventor e o $\S 1 .{ }^{\circ}$, bem como e principalmente o $\S$ único do art. 40, indica o direito creditorial, em benefício do interventor, e por decorrência exclusiva do pagamento.

A sub-rogação legal está perfeitamente instituída pelo $\S$ único do art. 40: "O interveniente voluntário que paga, fica sub-rogado em todos os direitos daquele cuja firma foi por êle honrada".

Eis gritante a diversidade de princípios nos dois departamentos jurídicos.

Abramos um parêntesis para consignar que o momento não é oportuno para o exame da desinteligência que há entre nossos comercialistas no tocante à amplitude dessa sub-rogação. Entendem uns, com Magarinos Tôrres à frente, que o interveniente, sempre $e$ invariàvelmente se sub-roga nos direitos daquele credor que foi pago; entendem outros, chefiados por Whitacker, que a sub-rogação se dá nos direitos daquele, cuja firma foi honrada pelo interveniente. Para uns transmitem-se, pela sub-rogação legal, os direitos daquele a quem se pagou; para outros, os direitos daquele por quem se pagou. Os primeiros se escravizam ao Pacto Uniforme de Haya, os últimos só fitam o $\S$ único do art. 40. Temos para nós, ao que pese a unanimidade dos escritores, que ambas as doutrinas pecam. A dos primeiros é inteiramente fruto de um engano, ou melhor de uma preocupação absoluta de aplicar direito alienígena, embora repelido expressamente por nossa legislação. A dos segundos amplia conceitos e os estabelece rígidos e infrangíveis, quando a lei muito claramente distingue hipóteses diferentes para diferentes consequiências. Se a intervenção surge quando o título está em protesto, ou seja em momento perigoso para o crédito e bom nome dos devedores, o interveniente sòmente "desonera $\mathrm{da}$ responsabilidade cambial todos os co-obrigados posteriores" à firma que foi por êle honrada. Portanto, se desobriga os posteriores sòmente, não desobriga positivamente a própria firma que foi honrada. Nesta hipótese, em conseqüência a sub-rogação abrange os direitos do portador do título, mas apenas compreendendo o devedor honrado e todos os co-devedores que lhe forem anteriores. Se, entretanto, a intervenção se dá por ato de absoluta liberalidade, sem qualquer premência a envolver os nomes dos obrigados (entendimento da expressão — voluntário - do § único do art. 40)

$$
-365-
$$

ficam de sob-rogados todos os devedores desde o que fôra honrado $\mathrm{e}$ os demais que lhe são posteriores. Persistem como obrigados os devedores anteriores àquele cuja firma foi honrada.

Para o trabalho atual não tem interêsse esta divergência de opiniões, pois que ela se projeta na maior ou menor amplitude dos direitos transmitidos pela sub-rogação. $O$ que importa é frisar que no Direito Cambiário há a sub-rogação legal em favor de um pagador, sem qualquer interêsse na dívida paga. $\mathrm{E}$ importa muito também dar relêvo e repetir que tal conseqüência não se verificaria jamais perante o Direito Civil.

Ante a disparidade, é de se perguntar: para onde pender? para as regras do Direito Civil ou para as do Direito Cambiário ?

Somos de opinião que se, devam adotar os princípios do Direito Cambiário, tal como o nosso direito prescreve, abandonadas as normas gerais traçadas pelo Pacto Uniforme de Haya, a fim de se evitarem as criações de negócios vantajosos, quiçá perseguições, por parte de quem disponha de numerário, contra inimigos que sejam devedores perante terceiros.

Quem paga uma dívida alheia, sem que para tanto tivesse a mais remota obrigação, pratica um ato de liberalidade e, para que seja realmente liberalidade, êle não se investe de direitos contra a pessoa em cujo benefício efetuou o pagamento, mas assume a sua posição na relação obrigacional, sub-rogando-se nos seus direitos contra possíveis co-obrigados anteriores, e desonerando qualquer outro desobrigado posterior.

Deverá o interveniente determinar o nome do devedor que é honrado por seu pagamento e, se o não fizer, entender-se-á que beneficiou os devedores principais.

Esta regra deveria prevalecer em qualquer hipótese e em qualquer momento, estivessem ou não os devedores na iminência de protestos ou de execução, prevalecendo a opinião sustentada por José Maria Whitacker e decorrente do $\S$ único do art. $40 \mathrm{da}$ lei 2.044 , sem o restritivo da última parte do $\S 1 .^{\circ}$ do art. 35 da cit. lei.

Se o beneficiado fôr o devedor principal, sem portanto qualquer direito creditório em que possa se investir o interventor, restará a êste um crédito contra o favorecido, mas com exclusivo assento no enriquecimento indébito, sem nenhum traço ligando seu crédito com a dívida saldada.

Desta sorte, parece-nos, ficam respeitados todos os elementos, que concorrem ao inesperado e gracioso aparecimento do interventor

A liberalidade não se transmuda em arma contra o beneficiado, evitados assim os temores de Giórgio Gịorgi, ao mesmo passo que 24 - R. D. 1..$^{\circ}$ Vol. 


$$
-366-
$$

a vontade de agraciar só recai na pessoa visada ou naqueles que; contra esta, poderiam usar do direito regressivo, mantendo simultâneamente vívida a obrigação dos que, contra quem, o benefiado poderia agir para exigir a satisfação da obrigação.

A vontade do generoso interveniente ficará inteiramente respeitada e só limitada pela munificência amplamente interpretada.

No Brasil, quiçá na América Latina, se pode adotar semelhante doutrina, porque aqui se compreende e se admite a magnanimidade a distribuir manirrotamente favores, sem visar proveitos, sem especular vantagens. Somos um povo capaz de consignar, em 1908, um $\S$ único do art. 40 da lei 2.044 , contrariando o espírito ganancioso e egoístico do europeu, estampado no Pacto Uniforme de Haya, de 1907, e na Conferência Internacional para Unificação do Direito Cambiário, de Genebra, de 1930.

\section{RELATÓRIO E PARECER}

\section{Relator: BRUNO DE MENDONCSA LIMA}

$\mathrm{O}$ autor mostra a divergência que há entre as normas que disciplinam a sub-rogação legal, conforme se trate de dívida civil ou dívida cambial. Recorda a conhecida distinção entre sub-rogação legal e sub-rogação convencional. De acôrdo com a lei civil (Cód. Civ. art. 985), a sub-rogação legal só se opera, quando o terceiro que paga tem interêsse ligado à própria dívida, como por exemplo, o adquirente do imóvel hipotecado que paga ao credor hipotecário. Fora de tais casos, o terceiro que paga por mera liberalidade, não se torna sub-rogado, e só tem contra o devedor ação de locupletamento. Em Direito Comercial, relativamente aos títulos cambiários, o pagamento feito por terceiro, tenha ou não algum interêsse ligado à dívida, como o interveniente, opera a sub-rogação. Analisa os efeitos da intervenção, e as divergências existentes entre os. doutos a respeito. Distingue a situação do interveniente que paga um título na iminência de protesto, da situação do que paga sem que haja essa situação de constrangimento.

Entende que deveria sempre prevalecer a regra segundo a qual o interveniente deverá determinar o nome do devedor que é honrado pelo pagamento de terceiro, e se o não fizer, entender-se-á que beneficiou o devedor principal. Mostra que a nossa lei cambial de 1908 admite a intervenção desinteressada e liberal, o que já não acontece com o Pacto da Lei Uniforme de Haia e com o que foi resolvido na Conferência Internacional para unificação do Direito. Cambiário (Genebra, 1930).

$$
-367-
$$

Propõe o autor da tese que aquêle que paga dívida alheia, sem que tenha a mais remota obrigação de pagá-la, assuma posição na relação obrigacional, sub-rogando-se nos seus direitos contra possíveis co-obrigados anteriores, e desonerando qualquer outro desobrigado posterior, disciplinando-se a sub-rogação pelas mesmas regras, quer se trate de obrigação civil ou comercial, cambial ou não.

A tese aborda um dos muitos casos em que relações ou situacões jurídicas idênticas são disciplinadas de modo diverso pelo $\mathrm{Di}$ reito Civil e pelo Direito Comercial. É o que acontece também com diversos casos de prescrição e até com a admissibilidade da prova testemunhal.

Sem dúvida é aconselhável tais divergências irem desaparecendo e que se conservem apenas aquelas em que a índole dos institutos. exija a distinção.

Assim, parece-me aceitável que o legislador estabeleça um critério único para a sub-rogação, quer se trate de obrigação civil, quer de obrigação comercial.

Bruno de Mendonça Lima

Faculdade de Direito de Pelotas.

Discutido e aprovado o parecer do sr. relator e recomendada a sua aprovação ao plenário.

Pôrto Alegre, 17 de agôsto de 1.950.

Antônio Martins Filho

Paulo Barbosa Lessa

José Baptista Neto 